\title{
Seismic Hazard Assessment for Thuong Tan-Tan My Quarries (Vietnam)
}

\section{Cao DINH TRONG ${ }^{1, *)}$, Xuan-Nam BUI ${ }^{2)}$, Pham NAM HUNG ${ }^{1)}$, Thai ANH TUAN ${ }^{1)}$, Mai XUAN BACH ${ }^{1)}$, Pham CONG KHAI'), Nguyen VIET NGHIA ${ }^{2)}$, Cao DINH TRIEU ${ }^{3)}$}

\footnotetext{
1) Institute of Geophysics, VAST, Hanoi, Vietnam; email: trongcd3284@gmail.com; pnhungigp@yahoo.com; tuan160680@yahoo.com; mxbach@yahoo.com;

2) Hanoi University of Mining and Geology, Hanoi, Vietnam; email buixuannam@humg.edu.vn; phamcongkhai@humg.edu.vn; nguyenvietnghia@humg.edu.vn

3) Institute for Applied Geophysics, VUSTA, Hanoi, Vietnam; email: cdtrieu@gmail.com
}

http://doi.org/10.29227/IM-2020-02-21

Submission date: 06-03-2020 | Review date: 22-09-2020

\section{Abstract}

This paper presents the seismic hazard assessment for Thuong Tan-Tan My quarries in Di An commune, Binh Duong province, Vietnam. Combination methods of gravity and magneto-telluric were used to estimate the dip angle and the width of the seismic source. The highest water column of $160 \mathrm{~m}$ will cause direct stress on the reservoir bottom with a maximum value of $1535.600 \mathrm{kPa}$ and Coulomb stress of $68.693 \mathrm{kPa}$ (at a depth of $2 \mathrm{~km}$ ). The typical components of natural earthquake hazard (Mn.max =5.0, depth of $10 \mathrm{~km})$ in Thuong Tan - Tan My reservoir have the following values: peak ground acceleration PGA $=0.073 \mathrm{~g} \div 0.212 \mathrm{~g}$; peak ground velocity $P G V=2.662 \mathrm{~cm} / \mathrm{s} \div 7.984 \mathrm{~cm} / \mathrm{s}$; peak ground displacement $P G D=0.706 \mathrm{~cm} \div 1.918 \mathrm{~cm}$ at $10 \%$ probability of exceedance in 50 years. The typical components of triggered earthquake hazard (Mtr.max $=3.5$, depth of $6 \mathrm{~km}$ ) in Thuong Tan - Tan My reservoir have the following values: peak ground acceleration $P G A=0.024 \mathrm{~g} \div 0.172 \mathrm{~g}$; peak ground velocity $P G V=0 \div 5.484 \mathrm{~cm} / \mathrm{s}$; peak ground displacement $P G D=0.061 \mathrm{~cm} \div 0.461 \mathrm{~cm}$ at $10 \%$ probability of exceedance in 50 years.

Keywords: quarry, Thuong Tan, Tan My, seismic source, triggered earthquake, maximum credible earthquake, incremental stress, Coulomb stress, seismic hazard

\section{Introduction}

Thuong Tan-Tan My building stone quarries consist of 17 quarries (13 quarries in Thuong Tan commune and four quarries in Tan My commune) located in Bac Tan Uyen district, Binh Duong province, Vietnam. These are open-pit quarries, exploiting Andesite extrusive sedimentary rocks (aged T3-J) under the weathered overburden of approximately $1 \mathrm{~m}$, on the terrain of 10-20 m height. Currently, these 17 quarries are exploited at different levels, from $-30 \mathrm{~m}$ to $-100 \mathrm{~m}$ (Fig. 1). Due to the great demand for building stones, the Binh Duong Provincial People's Committee has proposed connecting Thuong TanTan My quarries for exploitation to $-150 \mathrm{~m}$ and then converting this pit into a reservoir. According to the proposed plan, the connection and expansion of Thuong Tan-Tan My quarries will create a pit of $37.0 \mathrm{~km}^{2}$ with a depth of over $160 \div 170 \mathrm{~m}$ (up to the level of $-150 \mathrm{~m}$ and the terrain height of $10-20 \mathrm{~m}$ ).

One of the important tasks in evaluating the environmental impact on the exploitation method at Thuong Tan-Tan My quarries is the seismic hazard assessment which is assigned to the Institute for Applied Geophysics - VUSTA (Vietnam Union of Science and Technology Association). This paper concisely presents the methodology and results of this task with the following contents: determination of seismic source; assessment of maximum credible earthquake; calculation of incremental stress and Coulomb stress in case of water impoundment; and seismic hazard assessment for Thuong TanTan My quarries.

UAV technology has been used to collect topographic data for related researches (Dieu Tien Bui, et al., 2017; Nguy- en Quoc Long, et al., 2019; Bui, X.N., et al., 2019; Long, et al., 2020).

\section{Determination of seismic source and assessment of max- imum credible earthquake}

Thuong Tan-Tan My quarries are located in the Sai Gon River fault zone, dividing the Da Lat - Can Tho structural block into two sub-blocks (Hung Cat Nguyen, et al., 2009): Da Lat in the north and Can Tho in the south. The fault acts as a dynamic hinge in Cenozoic between two different tectonic regimes: uplift, denudation during the Cenozoic in Da Lat subblock in the northeast and subsidence, Cenozoic sedimentary fill, with the greatest thickness of $2100 \mathrm{~m}$ (Tra Cu basin) in Can Tho sub-block. The depth of influence of this fault zone is through the Earth's crust (over $30 \mathrm{~km}$ ), and the sphere of influence is $20 \div 30 \mathrm{~km}$. This fault zone nearly coincides with the photo

lineament length-density anomaly strip and the DEM-Lineament length-density anomaly reaches $200 \div 300$ $\mathrm{m} / \mathrm{km} 2$ (Linh Do Van, et al., 2008). The dextral displacement amplitude of rivers based on results of Landsat image analysis in 2002 is $500 \div 2000 \mathrm{~m}$ (Linh Do Van, et al., 2008). The largest vertical displacement amplitude of the Cenozoic sedimentary basement is $330 \div 446 \mathrm{~m}$ (Linh Do Van, et al., 2008). The latest research results (Linh Do Van, et al., 2008; Hung Cat Nguyen, et al., 2009; Nam Bui Xuan, et al., 2020) show that:

- The Sai Gon River fault zone is likely to be active in the modern period, including the Sai Gon River main fault and two accompanying faults: Dong Nai River and Thien Tan - 


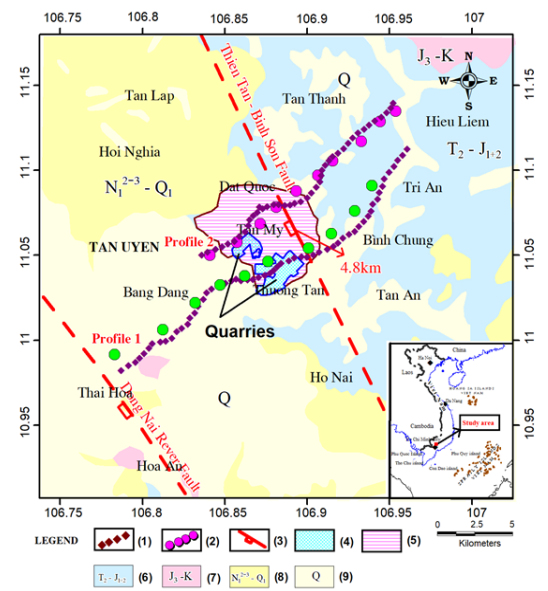

Fig. 1. Map of gravity and magneto-telluric measurement profiles for studying the structure of seismic source: 1 - Gravity measurement profile; 2 Magnetotelluric measurement profile; 3 - Faults, the Thuong Tan - Tan My segment has the length of $4.8 \mathrm{~km}$ (Trong Cao Dinh et al., 2018); 4 - Currently exploited quarries; 5 - Thuong Tan -Tan My quarries planned to be expanded (the area of $37.0 \mathrm{~km}^{2}$, up to the level - $150 \mathrm{~m}$ ); 6 - Rhyolite, tuff, shale, sandstone, siltstone (Middle Triassic - Early Jura); 7 - Andesite, tuff andesite, sandstone (Late Jura - Cretaceous); 8 - Sand, grit, pebble, gravel, calcareous sand, sand (Middle Neogene - Early Quaternary); 9 - Sand loam, pebble, grave, coral limestone (Quaternary)

Rys. 1. Mapa rozmieszczenia pomiarów grawitacyjnych i magneto-tellurycznych do badania struktury źródła sejsmicznego: 1-Przekrój pomiaru grawitacji; przekrój pomiaru 2-magnetotellurycznego; 3-uskoki, odcinek Thuong Tan-Tan My ma długość 4,8 km (Trong Cao Dinh et al., 2018); 4-eksploatowane kamieniołomy; 5-Thuong Tan -Tan My kamieniołomy planowane do rozbudowy (powierzchnia 37,0 km², do poziomu -150 m); 6- Ryolit, tuf, łupek ilasty, piaskowiec, mułowiec (trias środkowy - wczesna Jura); 7- Andezyt, tuf andezyt, piaskowiec (późna jura - kreda); 8-Piasek, grys, żwir, żwir, piasek wapienny, piasek (środkowy neogen - wczesny czwartorzęd); 9- Ił piaskowy, kamyk, grobowiec, wapień koralowy (czwartorzęd)

Binh Son which are predicted to generate earthquakes with Mn.max of 5.5, and 5.0, respectively.

- The Thien Tan - Binh Son seismic fault, which directly affects to Thuong Tan-Tan My quarries, has Mn.max = 5.0.

\section{Determination of the structure of seismic source}

A detailed assessment of seismic source includes structure (width, length, depth); dip angle of fault; and fracturing characteristics of rocks (through density and resistivity values). These are important parameters used to assess the magnitude of earthquakes which can possibly occur. In this paper, the authors have proposed using a combination of methods to determine the seismic source as follows:

$1 /$ The length of the seismic source was determined on the basis that (Trieu Cao Dinh, 2010; Trieu Cao Dinh, Vinh Nguyen Duc, 2012) the source segment (fault) is defined as a boundary dividing structural blocks of the Earth's crust with different composition and geophysical characteristics, and dividing gravitational and magnetic fields with the certain contrast. This boundary causes sudden changes in the depth and the altitude of basic boundary surfaces in the Earth's crust and sedimentary layers. They are clearly shown on modern topography, on satellite images or DEM map (Hung Cat Nguyen, et al., 2009), creating special topographic and geomorphologic elements or controlling the formation of Quaternary and modern sedimentary basins, with manifestations of earthquake, landslide, and neotectonic and modern deformations.

2/ The width, dip angle and fracturing characteristics of rocks of the source were determined using highly-detailed gravity method (gravimeter CG3, made in Canada) and magneto-telluric (AGCOS-Advanced Geophysical Operations and Services Inc., made in Canada) (Fig. 1):

a- Highly-detailed gravity measurement was carried out along two profiles (at the scale of 1:25000) in Thuong Tan-Tan
My quarries in order to calculate the maximum horizontal gradient (Gmax) and normalized full gradient (GH) of Bouguer gravity anomaly, for determination of fault locations (Trieu Cao Dinh, 2005; Kha Tran Van, et al., 2018; Nam Bui Xuan, et al., 2020).

b- Magneto-telluric measurement was conducted on two profiles (at the scale of 1:25000) perpendicular to the Thien Tan - Binh Son active fault zone (nearly coinciding with gravity profiles), serving the study on structural characteristics of this seismic source (Fig. 1).

c- Structural model of Thien Tan - Binh Son seismic source to a depth of $12 \mathrm{~km}$ is described in Figure 2. Based on the results of this study, we can evaluate the structural characteristics of seismic source, which can affect Thuong Tan-Tan My quarries, as follows: source length $\mathrm{L}=4.8 \mathrm{~km}$ (Trong Cao Dinh et al., 2018); source width $\mathrm{W}=2.8 \mathrm{~km}$ (Figure 2b), and dip angle of fault $\alpha=75^{\circ}$ (Fig. 2b).

\section{Assessment of maximum credible earthquake occurrence}

1/ The maximum natural earthquake (Mn.max) in the Thuong Tan - Tan My quarries and adjacent area

Vietnamese seismologists often use empirical formulas from Wells and Copersmith (1994) and Trieu Cao Dinh $(2002,2010)$ in assessing the maximum credible earthquake. Although these two formulas have different coefficients, they always give similar results (Hung Cat Nguyen, et al., 2009; Trong C. D., 2016; Nam Bui Xuan, et al., 2020). These two formulas were also applied in estimation of the maximum credible natural earthquake in the Thien Tan - Binh Son source segment, which shows Mn.max = 5.0. This value is consistent with the previous research results (Hung Cat Nguyen, et al., 2009; Trong Cao Dinh, et al., 2018; Nam Bui Xuan, et al., 2020).

2/ The maximum triggered earthquake (Mtr.max) in the Thuong Tan - Tan My reservoir after impoundment: 

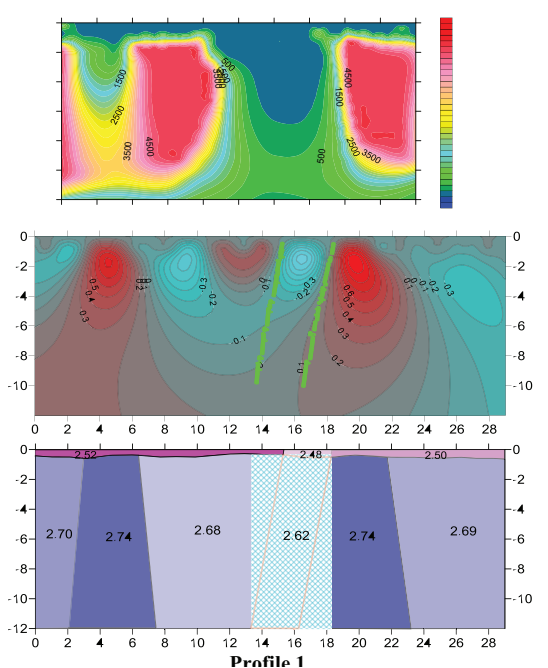
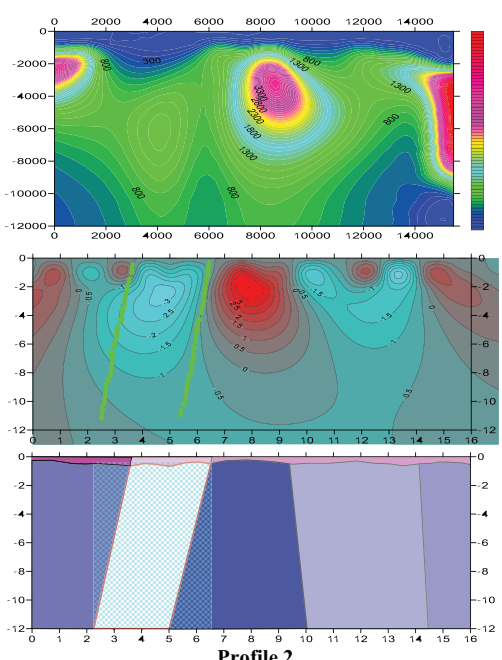

Profile 2

Fig. 2. Result of study on deep geological structure (using Oasis Montaj Software) along with two profiles: a) Resistance value; b) normalized full gradient (GH) value and location of maximum horizontal gradient (Gmax) point (green color); c) Structure density model (the numbers in the Fig.c are the densities of the rocks in $\mathrm{g} / \mathrm{cm}^{3}$ )

Rys. 2. Wynik badań głębokiej struktury geologicznej (przy użyciu oprogramowania Oasis Montaj) w dwóch profilach: a) Wartość oporu; b) znormalizowana wartość pełnego gradientu (GH) i położenie punktu maksymalnego gradientu poziomego (Gmax) (kolor zielony); c) Model gęstości struktury (liczby na rys. c to gęstości skał wg/ $\mathrm{cm}^{3}$ )
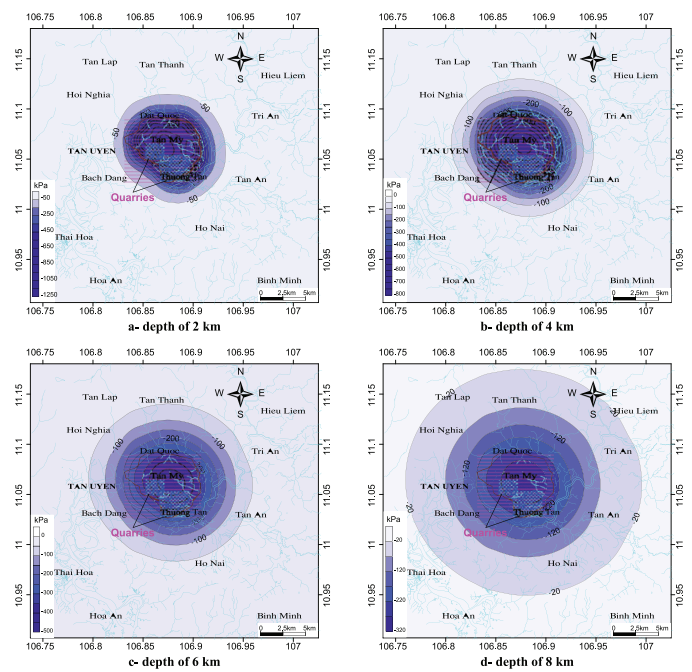

Fig. 3. Stress according to the vertical component at: a- depth of $2 \mathrm{~km}$; b- depth of $4 \mathrm{~km} ; \mathrm{c}$ - depth of $6 \mathrm{~km}$; and d- depth of $8 \mathrm{~km}$ (water column of $130 \mathrm{~m}$ ) Rys. 3. Naprężenie w zależności od składowej pionowej na: a- głębokości 2 km; b- głębokość 4 km; c- głębokość 6 km; id- głębokość 8 km (słup wody $130 \mathrm{~m}$ )

After the Thuong Tan - Tan My pit is exploited to - $150 \mathrm{~m}$, the water will be impounded, which can generate triggered earthquake (Gupta H.K, 2002; Trieu C. D., et al., 2014; Trong C. D., et al, 2016). Currently, there is no perfect formula for predicting the maximum magnitude of the triggered earthquake in the reservoir; however, Mtr.max is always supposed to be smaller than Mn.max with the difference of at least one magnitude unit (M) (Gupta H.K, 2002; Trieu Cao Dinh, et al., 2014; Trong Cao Dinh, et al., 2016). Trong Cao Dinh, et al. (2016) suggested that Mtr.max does not exceed the value (bn/bkt)* Mn.max (bn and bkt are the b values in the function of frequency and natural earthquake magnitude, and that of frequency and triggered earthquake magnitude, respectively; Gutenberg-Richter function). Mtr.max approximates to (Htr/ Hn) ${ }^{\star}$ Mn.max (Trong Cao Dinh, et al., 2016). Supposing that the thickness of the active layer of the triggered earthquake (Htr) and of the natural earthquake $(\mathrm{Hn})$ is related to the maximum credible earthquake magnitude, Mtr.max value in Thuong Tan-Tan My reservoir will not exceed 3.5 (The thickness of the active layer of natural earthquake in south Central Vietnam is about $17 \mathrm{~km}$ and that of the triggered earthquake in Vietnam is about $8 \mathrm{~km}$ ).

\section{Calculation of incremental stress and Coulomb stress in case of water impoundment \\ Calculation of incremental stress on the reservoir bottom af- ter the impoundment}

Both $2 \mathrm{D}$ and $3 \mathrm{D}$ problems can be used to calculate the incremental stress field and subsidence of the reservoir bottom. In the case of $3 \mathrm{D}$ problem, the reservoir was divided into the area elements of a $\mathrm{x}$ a $\mathrm{km} 2$ by a set of orthogonal straight lines. After determining the water depth (hi) for each area element, we had the vertical force $\mathrm{Fi}=\rho g a 2 h i$ at the centre of each area that can replace the water column pressure. With 
Tab. 1. The maximum value of incremental stress with different scenarios of reservoir depth Tab. 1. Maksymalna wartość przyrostowego naprężenia przy różnych scenariuszach głębokości zbiornika

\begin{tabular}{|c|c|c|c|c|}
\hline \multirow{2}{*}{$\begin{array}{l}\text { Scenario of } \\
\text { reservoir } \\
\text { depth }\end{array}$} & \multicolumn{3}{|c|}{ The maximum value of incremental stress at different depths } & \multirow{2}{*}{$\frac{(\mathrm{kPa}=0.01 \text { bar })}{8 \mathrm{~km}}$} \\
\hline & $2 \mathrm{~km}$ & $4 \mathrm{~km}$ & $6 \mathrm{~km}$ & \\
\hline $130 \mathrm{~m}$ & 1247.700 & 767.690 & 481.650 & 314.870 \\
\hline $160 \mathrm{~m}$ & 1535.600 & 944.850 & 592.800 & 387.540 \\
\hline
\end{tabular}
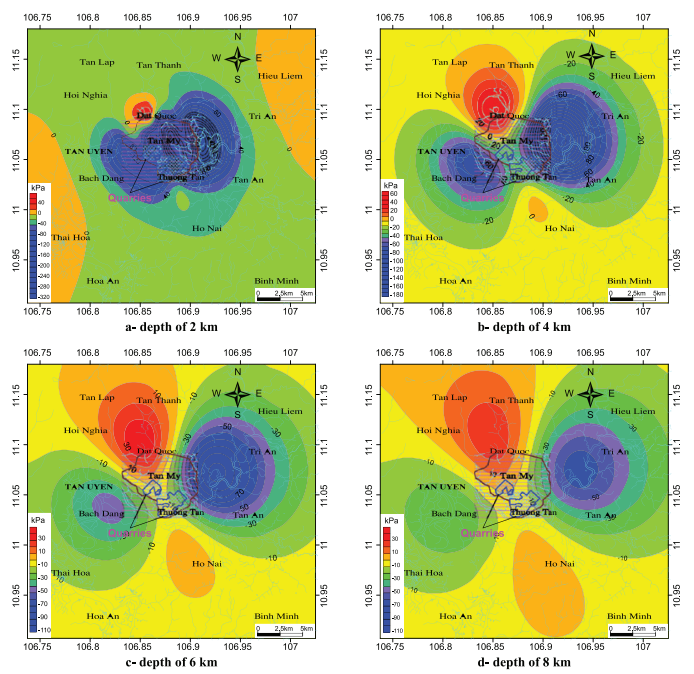

Fig. 5. Coulomb stress field caused by reservoir load at: a- depth of $2 \mathrm{~km}$; b- depth of $4 \mathrm{~km}$; c- depth of $6 \mathrm{~km}$; and d- depth of $8 \mathrm{~km}$ (water column of $130 \mathrm{~m}$ ) Rys. 5. Pole naprężeń kulombowskich wywołane obciążeniem zbiornika na: a- głębokości 2 km; b- głębokość 4 km; c- głębokość 6 km; idgłębokość $8 \mathrm{~km}$ (słup wody $130 \mathrm{~m}$ )

the $\mathrm{X}^{\prime} \mathrm{X}$ axis towards the east, the $\mathrm{Y}^{\prime} \mathrm{Y}$ axis towards the north and the $\mathrm{Z} Z \mathrm{Z}$ axis downwards, three normal stress components and one shear stress component at any point $\mathrm{P}$ were calculated according to the following formulas (Kalpna G., Chander R., 2000; Kalpna G., Gupta H.K., 2008; Kalpna G., Tuan T.A., Rao N.P., 2016):

$$
\begin{aligned}
& \sigma_{r}=\frac{F}{2 \pi}\left[\frac{1-2 \gamma}{r^{2}}\left(1-\frac{z}{R}\right)-\frac{3 r^{2} z}{R^{5}}\right] \\
& \sigma_{z}=\frac{3 F}{2 \pi} \frac{z^{3}}{R^{5}} \\
& \sigma_{\theta}=\frac{F}{2 \pi}(1-2 \gamma)\left(-\frac{1}{r^{2}}+\frac{z}{r^{2} R}+\frac{z}{R^{2}}\right) \\
& \tau_{x z}=-\frac{3 F}{2 \pi} \frac{r z^{2}}{R^{5}}
\end{aligned}
$$

Where: $v$ is Poisson's ratio; $R=\sqrt{ }\left(x^{2}+y^{2}+z^{2}\right)$ - the distance from the origin to the point $\mathrm{P}(\mathrm{x}, \mathrm{y}, \mathrm{z})$ and its projection given by $r=\sqrt{ }\left(x^{2}+y^{2}\right)$.

To add the distribution of $\mathrm{F}$ forces, they were converted to Cartesian coordinate system according to the correlation:

$$
\begin{aligned}
& \sigma_{x}=\sigma_{\theta} \sin ^{2} \theta+\sigma_{r} \cos ^{2} \theta \\
& \tau_{x y}=\left(\sigma_{r}-\sigma_{\theta}\right) \sin \theta \cos \theta \\
& \sigma_{y}=\sigma_{r} \sin ^{2} \theta+\sigma_{\theta} \cos ^{2} \theta \\
& \tau_{x y}=\tau_{x z} \cos \theta \\
& \sigma_{z}=\sigma_{z} \\
& \tau_{y z}=\tau_{r z} \sin \theta
\end{aligned}
$$

Where, the azimuth $\theta=\operatorname{Artan}(\mathrm{y} / \mathrm{x})$ is calculated from the east to the north (counterclockwise).

Stress is considered as the result of total loading on a point collected by taking the total distribution of all $\mathrm{F}$ forces for six stress components: $\sigma \mathrm{x}, \sigma \mathrm{y}, \sigma \mathrm{z}, \sigma \mathrm{xy}, \sigma \mathrm{yz}, \sigma \mathrm{zx}$.

From these parameters, we selected the normal downward stress $\sigma_{z z}$ and the maximum shear stress $\tau \max =(\sigma 1-\sigma 3)$.
In addition, under the pressure of reservoir load, the vertical subsidence $\Delta \mathrm{d}(\mathrm{m})$ due to the effect of total $\mathrm{F}$ force was calculated by the formula:

$$
\Delta d=\frac{F}{2 \pi E}\left[\frac{(1+v) Z^{2}}{R^{3}}+2 \frac{\left(1-v^{2}\right)}{R}\right]
$$

Where: $\mathrm{E}$ is Young's modulus; $\mathrm{R}$ is the distance of point $\mathrm{P}$ from the origin. The subsidence is caused by all the point forces and the total subsidence $\mathrm{d}$ at point $\mathrm{P}$ is the result of reservoir load.

The calculation of incremental stress on the bottom of Thuong Tan-Tan My reservoir after the impoundment was carried out at the depths: $2 \mathrm{~km}, 4 \mathrm{~km}, 6 \mathrm{~km}$ and $8 \mathrm{~km}$ (the hypocenter of a triggered earthquake is usually located at a depth from $2 \mathrm{~km}$ to $8 \mathrm{~km}$ ). Results of stress calculation at different depths with water columns of $130 \mathrm{~m}$ and $160 \mathrm{~m}$ (corresponding levels of reservoir bottom of $-120 \mathrm{~m}$ and $-150 \mathrm{~m}$, dam height of $15 \mathrm{~m}$ at these levels, water rise of $5 \mathrm{~m}$ from dam crest) are presented in Fig. $3 \& 4$ and the maximum value of this incremental stress is shown in Tab.

Calculation of Coulomb stress due to the effect of the water column on the bottom of Thuong Tan - Tan My reservoir

According to Bell and Nur (1978), the change of Coulomb stress $(\Delta S)$ caused by reservoir impoundment was determined as follows: $\Delta S=\Delta \tau-\mu\left(\Delta \sigma_{n}-\Delta P\right)$, where $\Delta \tau$ and $\Delta \sigma_{n}$ correspond to the changes of shear stress and normal stress which are caused by reservoir loading on fault surface, $\Delta \mathrm{P}$ is the change of pore pressure, and $\mu$ is the coefficient of friction. The increase of $\Delta \tau$ and the decrease of $\Delta \sigma_{n}$ mean that $\Delta S$ has a positive value, which will stimulate the fault activity and vice 
Tab. 2. The maximum value of Coulomb stress caused by reservoir loading with different scenarios of reservoir depth

Tab. 2. Maksymalna wartość naprężenia Coulomba wywołanego obciążeniem zbiornika przy różnych scenariuszach głębokości zbiornika

\begin{tabular}{|c|c|c|c|c|}
\hline \multirow{2}{*}{$\begin{array}{c}\text { Scenario of } \\
\text { reservoir depth }\end{array}$} & \multicolumn{4}{|c|}{ The maximum value of Coulomb stress at different depths (kPa) } \\
\cline { 2 - 5 } & $\mathbf{2} \mathbf{k m}$ & $\mathbf{4 k m}$ & $\mathbf{6 k m}$ & $\mathbf{8 k m}$ \\
\hline $130 \mathrm{~m}$ & 55.813 & 50.857 & 38.632 & 27.650 \\
\hline $160 \mathrm{~m}$ & 68.693 & 62.593 & 47.547 & 34.031 \\
\hline
\end{tabular}
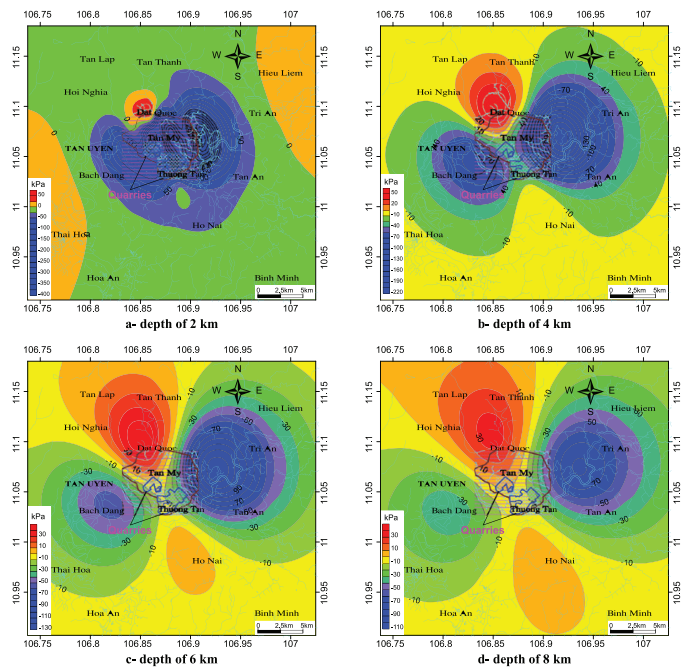

Fig. 6. Coulomb stress field caused by reservoir load at: a- depth of $2 \mathrm{~km}$; b- depth of $4 \mathrm{~km}$; c- depth of $6 \mathrm{~km}$; and d- depth of $8 \mathrm{~km}$ (water column of $160 \mathrm{~m}$ ) Rys. 6. Pole naprężeń kulombowskich wywołane obciążeniem zbiornika na: a- głębokości 2 km; b- głębokość 4 km; c- głębokość 6 km; id- głębokość $8 \mathrm{~km}$ (słup wody $160 \mathrm{~m}$ )

versa. The role of pore pressure always promotes the fault activity due to the lubrication on the fault surface and decreases the shear stress component $\Delta \tau$

Based on the above theoretical basis, the research team has written a program in Matlab language to calculate stress components and Coulomb stress caused by reservoir loading on the study area.

The reservoir was divided into small blocks, the parameters of length, width and depth at each block were determined. The fault parameters consisting of strike angle, dip angle and rake angle were taken in to account the change of stress field. In the study area, Thien Tan - Binh Son River right-lateral strike slip fault near the reservoir is considered as an active fault, and the parameters of this fault (strike angle $=140 \mathrm{o}$, dip angle $=75^{\circ}$, rake angle $=180^{\circ}$ ) were included in the calculation of Coulomb stress (Hung C. N, et al., 2009). The study area is divided into grid of $0.00180 \times 0.00180$; with Poisson's ratio $v=0.25$; Skempton's coefficient $B=0.7$; coefficient of friction $\mu=0.65$ (Tuan T. A, et al., 2017).

From the above input parameters, the calculations are based on the scenario in which the reservoir is fully impounded, and the tectonic stress field in the area is unchanged at the calculation time. Components of Coulomb stress field were calculated with reservoir depths of $130 \mathrm{~m}$ and $160 \mathrm{~m}$ at $2 \mathrm{~km}$, $4 \mathrm{~km}, 6 \mathrm{~km}$ and $8 \mathrm{~km}$ depth, respectively (Tab. 2, Fig. 5 \& 6). The results show that the areas with a positive value of Coulomb stress $\Delta \mathrm{S}$ are at risk of a triggered earthquake when the reservoir is fully impounded. These results allow us to delineate the areas at risk of a reservoir-triggered earthquake.

From the above input parameters, the calculations are based on the scenario in which the reservoir is fully impound- ed, and the tectonic stress field in the area is unchanged at the calculation time. Components of Coulomb stress field were calculated with reservoir depths of $130 \mathrm{~m}$ and $160 \mathrm{~m}$ at $2 \mathrm{~km}$, $4 \mathrm{~km}, 6 \mathrm{~km}$ and $8 \mathrm{~km}$ depth, respectively (Tab. 2, Fig. 5 \& 6). The results show that the areas with a positive value of Coulomb stress $\Delta S$ are at risk of a triggered earthquake when the reservoir is fully impounded. These results allow us to delineate the areas at risk of a reservoir-triggered earthquake.

\section{Seismic hazard assessment for Thuong Tan-Tan My quar- ries}

OQEngine software (using the function of ground motion attenuation from Campbell-Bozorgnia 2008 and seismic source model-SSM) was applied in seismic hazard assessment for Thuong Tan-Tan My quarries (GEM, 2020; Pagani, M., Monelli, D., Weatherill, G. A. and Garcia, J., 2014; Coppersmith, K., J. Bommer, K. Hanson, J. Unruh, R. Coppersmith, L. Wolf, R. Youngs, A. Rodriguez Marek, L. Al Atik and G. Toro, 2014; Marco Pagani, Julio Garcia, Valerio Poggi, and Graeme Weatherill, 2016).

The $10 \%$ probability of exceedance in 50 years was used in seismic hazard assessment (natural earthquake, Mn.max = 5.0; triggered earthquake, Mtr.max = 3.5) for Thuong Tan-Tan My quarries, which is shown in Figures 7, 8 and 9:

- Natural earthquake with Mn.max $=5.0$ will result in PSHA ( $10 \%$ probability of exceedance in 50 years) with the highest values at Thuong Tan-Tan My quarries as follows: peak ground acceleration PGA $=0.073 \mathrm{~g} \div 0.212 \mathrm{~g}$; peak ground velocity $P G V=2.662 \mathrm{~cm} / \mathrm{s} \div 7.984 \mathrm{~cm} / \mathrm{s}$; peak ground displacement $\mathrm{PGD}=0.706 \mathrm{~cm} \div 1.918 \mathrm{~cm}$. 

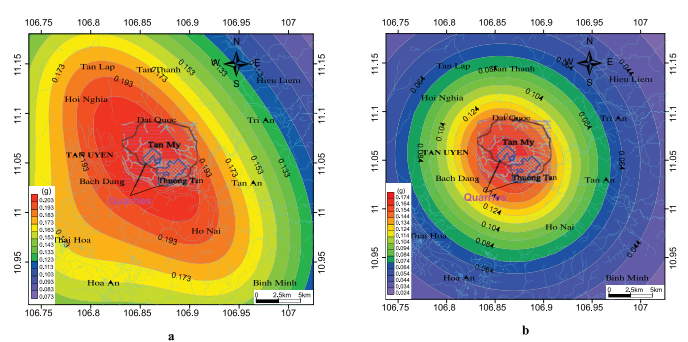

Fig. 7. Peak ground acceleration (PGA): a) Mn.max=5.0; b) Mtr.max=3.5

Rys. 7. Szczytowe przyspieszenie ziemi (PGA): a) Mn.max $=5.0$; b) Mtr.max $=3.5$
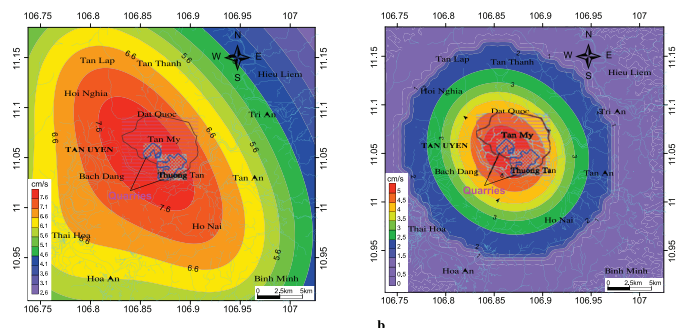

Fig. 8. Peak ground velocity (PGV): a) Mn.max=5.0; b) Mtr.max=3.5

Rys. 8. Szczytowa prędkość względem ziemi (PGV): a) Mn.max $=5.0$; b) Mtr.max $=3.5$
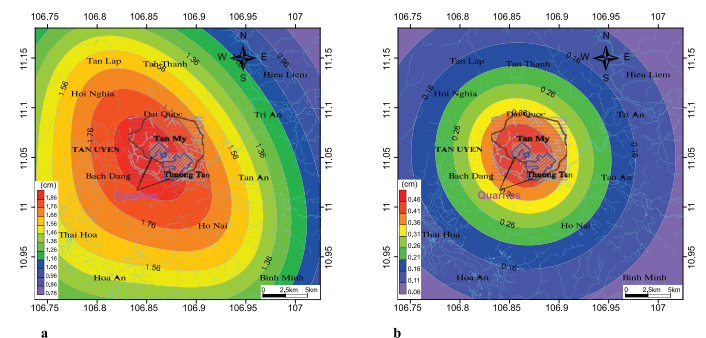

Fig. 9. Peak ground displacement (PGD): a) Mn.max=5.0; b) Mtr.max=3.5

Rys. 9. Maksymalne przemieszczenie ziemi (PGD): a) Mn.max=5.0; b) Mtr.max=3.5

- Triggered earthquake with Mtr.max $=3.5$ will lead to PSHA ( $10 \%$ probability of exceedance in 50 years) with the highest values at Thuong Tan-Tan My quarries as follows: peak ground acceleration PGA $=0.024 \mathrm{~g} \div 0.172 \mathrm{~g}$; peak ground velocity $P G V=0 \div 5.484 \mathrm{~cm} / \mathrm{s}$; peak ground displacement $\mathrm{PGD}=0.061 \mathrm{~cm} \div 0.461 \mathrm{~cm}$.

\section{Conclusion}

1. Within the Thuong Tan-Tan My quarries, there exist two seismic sources with the magnitude of natural earthquake Mn.max $=5.0$, namely Dong Nai River and Binh Long - Binh Chau. The source segment that is likely to generate the triggered earthquake (directly connected to Thuong Tan-Tan My reservoir) has the following structural characteristics: $4.8 \mathrm{~km}$ length; $2.8 \mathrm{~km}$ width; rake angle $=180 \mathrm{o}$; dip angle $=75 \mathrm{o}$ and Mtr.max $=3.5$.

2. The highest water column of $160 \mathrm{~m}$ will cause direct stress on the reservoir bottom with a maximum value of $1535.600 \mathrm{kPa}$ and Coulomb stress of $68.693 \mathrm{kPa}$ (at a depth of $2 \mathrm{~km}$ ). Compared to the breaking stress of rock in the earthquake, the calculated value is very small, only about $1 \%$. It acts as the promoting mechanism and only matters when the natural stress reaches its limit.
3. The typical components of natural earthquake hazard Mn.max $=5.0$ occurring at a depth of $10 \mathrm{~km}(10 \%$ probability of exceedance in 50 years) in Thuong Tan-Tan My reservoir have the following values: peak ground acceleration PGA $=$ $0.073 \mathrm{~g} \div 0.212 \mathrm{~g}$; peak ground velocity $\mathrm{PGV}=2.662 \mathrm{~cm} / \mathrm{s}$ $\div 7.984 \mathrm{~cm} / \mathrm{s}$; peak ground displacement $\mathrm{PGD}=0.706 \mathrm{~cm} \div$ $1.918 \mathrm{~cm}$.

4. The typical components of triggered earthquake hazard Mtr.max $=3.5$ occurring at a depth of $6 \mathrm{~km}(10 \%$ probability of exceedance in 50 years) in Thuong Tan-Tan My reservoir have the following values: peak ground acceleration PGA $=$ $0.024 \mathrm{~g} \div 0.172 \mathrm{~g}$; peak ground velocity $\mathrm{PGV}=0 \div 5.484 \mathrm{~cm} / \mathrm{s}$; peak ground displacement $P G D=0.061 \mathrm{~cm} \div 0.461 \mathrm{~cm}$.

\section{Acknowledgement}

This research was supported by Hanoi University of Mining and Geology (HUMG) and Institute for Applied Geophysics (VUSTA). We also thank the Center for Mining, Electro-Mechanical Research of HUMG for providing with data and fund in the scope of scientific research projects with the Department of Natural Resources and Environment of Binh Duong province. 


\section{Literature - References}

1. Advanced Geophysical Operations and Services Inc. Gepard-8 - User guide (2016).

2. Agcos. Gerard user manual ver. 2.2 (2016).

3. Bell, M.L.; Nur, A. Strength changes due to reservoir-induced pore pressure and stresses and application to Lake Oroville. J. Geophys. Res.: Solid Earth 83, 1978, 4469-4483.

4. Bui, X.N.; Choi, Y.; Atrushkevich, V.; Nguyen, H.; Tran, Q.H.; Long, N.Q. Hoang, H.T. Prediction of Blast Induced Ground Vibration Intensity in Open-Pit Mines Using Unmanned Aerial Vehicle and a Novel Intelligence System. Nat. Resour.Res. (2019)

5. Center of Electromagnetic Methods MicroKOR Ltd. Audiomagnetotellurics' Soundings System ACF-4M Manual (2008).

6. Coppersmith, K.; J. Bommer; K. Hanson; J. Unruh; R. Coppersmith; L. Wolf; R. Youngs; A. Rodriguez Marek; L. Al Atik; G. Toro. Hanford Site Wide Probabilistic Seismic Hazard Analysis, Report PNNL-23361 (2014), Pacific Northwest National Laboratory, Richland Washington.

7. Dieu Bui Tien And Et Al. Lightweight Unmanned Aerial Vehicle and Structure-from-Motion Photogrammetry for Generating Digital Surface Model for Open-Pit Coal Mine Area and Its Accuracy Assessment", International Conference on Geo-Spatial Technologies and Earth Resources, 17-33 (2017).

8. Gem. The OpenQuake-engine User Manual. Global Earthquake Model (GEM) Open-Quake Manual for Engine version 3.8.1. doi: 10.13117/Gem Openquake .Man. Engine.3.8.1, 183 pages (2020).

9. Geometrics Electromagnetic Instruments, Inc. Operation Manual For Stratagem Systems Running IMAGEM Ver. 2.19 (2007).

10. Gepard. Csamt User Guide (2016).

11. Gepard. Mt User Guide (2016).

12. Gupta, H.K.; Rastogi, B.K.; Narain, H. Common features of the reservoir-associated seismic activities. Bull. Seismol. Soc. Am. 62, 481- 492 (1972).

13. Gupta, H.K. Reservoir-induced earthquakes. Developments in Geotechnical Engineering, Elsevier, The Netherlands, 64 (2002).

14. Gupta, H.K. Et Al. Encyclopedia of Earth Sciences Series. Springer, The Netherlands (2011).

15. Hung Cat Nguyen; Et.As. Earthquake microzoning in Ho Chi Minh City. Final project report (Stored in South-Vietnam Geological Mapping Division, Institute of Geophysics). Ho Chi Minh City, 360 pages (2009), (in Vietnamese).

16. Kha Tran Van; Vuong Hoang Van; Thanh Do Duc; Hung Duong Quoc; Anh Le Duc. Improving a maximum horizontal gradient algorithm to determine geological body boundaries and fault systems based on gravity data. Journal of Applied Geophysics 152, 161-166 (2018).

17. Kalpna, G.; Chander, R. Green's function based stress diffusion solution in the porous elastic half space for time varying finite reservoir loads. Physics of the Earth and Planetary Interiors, 120, 93-101 (2000).

18. Kalpna, G.; Gupta, H.K. An integral equation algorithm for 3-D simulation of pore pressure in a porous elastic medium with heterogeneities. Geophysical Journal International, 175, 1245-1253 (2008).

19. Kalpna, G.; Tuan, T.A.; Rao N.P. Rapid and Delayed Earthquake Triggering by the Song Tranh 2 Reservoir, Vietnam. Bull. Seismol. Soc. Am., Vol. 106, No. 5, 2389-2394 (2016).

20. Linh Do Van; Chinh Vu Dinh; Chinh La Thi. The Pliocene - Quaternary tectonic stress field in South Vietnam and its influence on deformation of Pre-Cenozoic basement of Cuu Long basin. The 2nd International Scientific Conference "Fracture Basement Reservoir", PetroVietnam. 9-10/ September 2008, Vung Tau - Vietnam, pp. 51-62 (2008).

21. Maxim Smirnov; Toivo Korja; Lars Dynesius; Laust B. Pedersen; Erkki Laukkanen. Broadband Magnetotelluric Instruments for Near-surface and Lithospheric Studies of Electrical Conductivity: A Fennoscandia Pool of Magnetotelluric Instruments. Geophysica 44, 31-44 (2008).

22. Marco Pagani; Julio Garcia; Valerio Poggi; Graeme Weatherili. Probabilistic seismic hazard analysis: issues and challenges from the GEM perspective. 5th IASPEI/IAEE International Symposium: Effects of Surface Geology on Seismic Motion, August 15-17 (2016).

23. Nam Bui Xuan; Trong Cao Dinh; Long Nguyen Quoc; Bach Mai Xuan; Hung Trinh Le; Hien La Phu; Ropesh Goyal; Tuan Thai Anh; Hung Pham Nam. Assessment on maximum magnitude of natural and triggered earthquake when water is impounded in the mining pit: A case study in Nui Nho quarry, Vietnam based on gravity and magnetic data. Russian Journal of Earth Sciences, Vol. 20, ES1007, DOI:10.2205/2020ES000690 (2020). 
24. Nguyen Quoc Long, Bui Xuan Nam, Cao Xuan Cuong, Le Van Canh. An approach of mapping quarries in Vietnam using low-cost Unmanned Aerial Vehicles", International Journal of Sustainable Development, 11(2):199-210 (2019).

25. Nguyen Quoc Long, Ropesh Goyal, Bui Khac Luyen, Le Van Canh, Cao Xuan Cuong, Pham Van Chung, Bui Ngoc Quy, Xuan-Nam Bui. Influence of Flight Height on The Accuracy of UAV Derived Digital Elevation Model of Complex Terrain. Inzynieria Mineralna, Vol 45 (1), DOI: 10.29227/IM-2020-01-27 (2020).

26. Pagani, M.; Monelli, D.; Weatherill, G. A.; Garcia, J. The OpenQuake-engine Book: Hazard. Global Earthquake Model (GEM) Technical Report 2014-08, doi: 10.13117/-GEM.OPENQUAKE.TR2014.08, 67 pages (2014).

27. Trieu Cao Dinh. Seismic activity of Tuan Giao region and its vicinity. Journal of Science and Technology. Vol. 40, No. 5, Hanoi, pp. 40-51 (2002), (in Vietnamese).

28. Trieu C ao Dinh. Seismic hazards in Vietnam, Publishing House for Science and Technology, Hanoi, 182 pages (2010).

29. Trieu Cao Dinh; Trong Cao Dinh; Dung Le Van; Tuan Thai Anh; Van Dinh Quoc; Long Ha Vinh. Triggered earthquake study in Tranh River No. 2 (Vietnam) Hydropower Reservoir. Journal of the Geological Society of India, Volume 84, Issue 3, pp. 319-325 (2014).

30. Trieu Cao Dinh; Vinh Nguyen Duc. Fault segmentation for estimation of maximum earthquake in Vietnam. Journal of Geology, Series A, No. 331-332, Hanoi, pp. 59 - 68 (2012), (in Vietnamese).

31. Trong Cao Dinh; Duong Nguyen Anh; Tuan Thai Anh; Trieu Cao Dinh. Characteristics of triggered earthquake activity in Da River cascade hydropower plant. Journal of Geology, Series A, No. 361-362 (11-12), 2016. pp. 80-93 (in Vietnamese).

32. Trong Cao Dinh; Nam Bui Xuan; Tuan Thai Anh; Hung Pham Nam; Bach Mai Xuan. Risk assessment of Triggered earthquake occurrences in the quarries Thuong Tan III, IV and adjacent area cince the mining pit is impounded water. Journal of Mining and Earth Sciences Vol. 59, Issue 6 (2018), pp. 43 -55.

33. Tuan, T.A.; Rao, N.P.; Kalpna, G.; Trong, C.D.; Dung, L.V.; Chien, C.; Mallika K. Evidence that earthquakes have been triggered by reservoir in the Song Tranh 2 region, Vietnam. Journal of Seismology, Vol. 21, No. 5, pp, 2017. 1131-1143.

34. Wells, D. 1.; Coppersmith, K. J. New empirical relationship among magnitude, rupture length, rupture width, rupture area, and surface displacement. Bull. of the Seism. Soc. of America, 84/4, pp. 974 (1994).

Ocena zagrożenia sejsmicznego dla kamieniołomów na rẹonie Thuong Tan-Tan My (Wietnam) $W$ artykule przedstawiono ocenę zagrożenia sejsmicznego dla kamieniołomów na rejonie Thuong Tan-Tan My w gminie Di An w prowincji Binh Duong, Wietnamie. Do oszacowania kąta upadu i szerokości źródła sejsmicznego wykorzystano kombinację metod grawitacyjnych i magneto-tellurycznych. Najwyższy slup wody $160 \mathrm{~m}$ spowoduje bezpośrednie naprężenia na dnie zbiornika o maksymalnej wartości 1535,600 kPa i naprężeniu kulombowskim 68,693 kPa (na glębokości $2 \mathrm{~km}$ ). Typowe składowe naturalnego zagrożenia trzęsieniem ziemi (Mn.max = 5,0, głębokość $10 \mathrm{~km}$ ) w zbiorniku Thuong Tan-Tan My maja następujące wartości: szczytowe przyspieszenie gruntu $P G A=0,073 \mathrm{~g} \div 0,212 \mathrm{~g}$; szczytowa prędkość gruntu $P G V=2,662 \mathrm{~cm} / \mathrm{s} \div 7,984 \mathrm{~cm} / \mathrm{s} ;$ szczytowe przemieszczenie gruntu $P G D=0,706 \mathrm{~cm} \div 1,918 \mathrm{~cm}$ przy $10 \%$ prawdopodobieństwie przekroczenia za 50 lat. Typowe składowe wywotanego zagrożenia trzęsieniem ziemi (Mtr.max $=3,5$, glębokość $6 \mathrm{~km}) w$ zbiorniku Thuong Tan-Tan My maja następujace wartości: szczytowe przyspieszenie ziemi $P G A=0,024 \mathrm{~g} \div 0,172 \mathrm{~g}$; szczytowa prędkość gruntu $P G V=0 \div 5,484 \mathrm{~cm} / \mathrm{s}$; szczytowe przemieszczenie ziemi $P G D=0,061 \mathrm{~cm} \div 0,461 \mathrm{~cm}$ przy $10 \%$ prawdopodobieństwie $z a 50$ lat.

Słowa kluczowe: kamieniołomy, źródło sejsmiczne, trzęsienie ziemi, maksymalne wiarygodne trzęsienie ziemi, naprężenie przyrostowe, naprężenie coulomba, zagrożenie sejsmiczne 